\title{
SITUS OF INTANGIBLES IN SUITS AGAINST NONRESIDENT CLAIMANTS
}

\author{
BY FLETCHER R. ANDREWS †
}

ExERCISE by a court of jurisdiction in rem or quasi in rem is valid only if the property or res involved be within the territorial boundaries over which the court holds sway. ${ }^{2}$ If the subject matter of the action is real property or tangible personal property, it is comparatively simple to determine whether the res is within those boundaries. But when intangible property is involved, the problem becomes far more complex. Realistically, an intangible has no situs in the sense that tangible property has, and it is necessary, therefore, to act somewhat arbitrarily in assigning it one. ${ }^{3}$ The purpose of this Article is to investigate this difficult problem and to discover, if possible, what forms of intangibles are regarded as property for the purpose of jurisdiction in rcm, and what is the situs of each. The field of inquiry will be limited to suits involving a dispute with reference to the ownership of or some interest in the intangible in question, ${ }^{4}$ and will not include the attachment cases, except where reference to them may be helpful to a determination of the issue. In the interest of clarity, the various kinds of intangibles will be separately considered.

\section{Bonds}

A bond evidences an obligation. Conceivably, a court might hold that it is nothing more than the evidence of that obligation and consequently that the location of the bond is immaterial in determining the situs of the

$\dot{i}$ Professor of Law, Western Reserve University Law School.

1. For a discussion of actions in rem as opnosed to actions in fersonan, see Cool,; The Jurrisdiction of Sovercign States and the Confliet of Lazes (1931) 31 CoL L. Rew. 368; Cook, The Pourers of Couts in Equity (1915) 15 CoL. L. REx. 37, 46-47. For the line of demarcation between actions in rem and quasi in rem, see Beale, The Excreise of Jurisdiction in Rem to Compel Payment of a Delt (1913) 27 H.Asv. L. REv. 107, 109; Cook, The Powers of Courts of Equity (1915) 15 CoL. L. Rev. 37, 47. For the salie of simplicity the term in rem will be used to include actions quasi in rem where applieable.

2. The authorities upon this proposition are legion. See, for example, Balser v. Baker, Eccles \& Co., 242 U. S. 394 (1917). The Fourteenth Amendment to the Constitution permits constructive service upon nonresident defendants in actions in rem. Arndt v. Griggs, 134 U. S. 316 (1890); Roller v. Holly, 176 U. S. 398 (1900). Many other decisions might be cited in support of this statement. 1441.

3. See Goodrich, Conflict of Laws (2d ed. 1938) 141; (1932) 32 Col. L. Rev.

4. It is important to note that the situs of a given type of intangible may differ with the type of case involved. For instance, the situs of a debt is said to be at the domicil of the creditor for purposes of taxation, but at the domicil of the debtor for purposes of garnishment. See 1 BeAlE, Conflict of LAws (1935) 301-302. The type of action which is here the subject of inquiry will sometimes be referred to as the "conflicting claimant" case. 
debt. In that event, if a debt evidenced by a bond is to be considered property in connection with jurisdiction in rem, some other basis for situs must be found. This might be the domicil of the holder, the domicil of the obligor, or any place where the obligor is found. On the other hand, a court might regard the bond as property in itself, having a situs wherever located. Under this view the other enumerated elements would be of no importance.

Although under certain circumstances courts have not hesitated to hold that a debt is a res having its situs at the domicil of the obligor, ${ }^{\circ}$ this is not the law in the situation with which this study deals." Accorlingly, if domicil of the obligor does not suffice to give a situs for jurisdiction in rem, it naturally follows that no situs exists by reason of the obligor's presence. $^{7}$

There is left, then, a choice between the domicil of the holder and the place where the bonds are located. Either of the following fact situations should help materially in the solution of the problem.

1. The bonds are present, but the holder is a nonresident. The assumption of jurisdiction under such circumstances would establish a situs at the location of the bonds, although it would not necessarily preclude an alternative situs at the holder's domicil. On the other hand. refusal to take jurisdiction because of the nonresidence of the holder would establish the holder's domicil as the situs, to the exclusion of the locale of the bonds. ${ }^{8}$

5. See 1 Beale, loc. cit. supra note 4 (garnishment); Wyman v. Halstead, 109 U. S. 654,656 (administration).

6. In the following cases the court took jurisdiction without reference to the obligor's domicil: Bede Steam Shipping Co. v. New York Trust Co., 54 F. (2d) 658 (S. D. N. Y. 1931) ; First Trust Co. of St. Paul v. Matheson, 187 Minn. 468, 246 N. W. 1 (1932); Laughlin v. Wells Bldg. Co., 169 Wis. 50,171 N. W. 755 (1919). In the following cases the court refused jurisdiction without reference thereto: Chase v. Wetzlar, 225 U. S. 79 (1912) ; McLaughlin v. McLaughlin Real Estate Co., 162 App. Div. 644, 147 N. Y. Supp. 959 (2d Dep’t 1914) ; Hodgens v. Columbia Trust Co., 185 App. Div. 555, 173 N. Y. Supp. 304 (1st Dep't 1918) ; Cleveland National Bank v. Burrotghs Land Co., 10 Ohio App. 61 (1917); Gallagher v. Rogan, 322 Pa. 315, 185 Atl. 707 (1936).

In the absence of other factors, courts have refused to take jurisdiction in rcm at the obligor's domicil. Waverly v. Auditor of Public Accounts, 100 Ill. 354 (1881); Williams v. Fischlein, 144 App. Div. 244, 129 N. Y. Supp. 129 (2d Dep't 1911). Although it is true that in the former case the defendants were "the unknown owners" of the bonds, the court based its decision upon the fact that neither the bonds nor the owners were within the court's jurisdiction. Where the obligor's domicil and the bonds were outside the state, jurisdiction has been refused without giving weight to the former factor. Gilmore v. Robillard, 44 F. (2d) 295 (C. C. A. 9th, 1930); Von Hesse v. Mackaye, 55 Hun 365,8 N. Y. Supp. 894 (1st Dep't 1890) ; Huntzinger and Cake v. Philadelphin Coal Co., 11 Phila. 609 (Pa. C. P. 1876).

7. Von Hesse v. Mackaye, 55 Hun 365, 8 N. Y. Supp. 894 (1st Dep't 1890). No case has been found suggesting any such basis for situs. A holding to that effect by the court below in the Von Hesse case was reversed by the Appellate Division.

8. No cases have been found, however, with such simple fact situations. 
2. The action is brought at the holder's domicil, but the bonds are absent. Of course, if the holder were the only defendant and the court obtained jurisdiction in personam over him, the issue would not arise. The circumstances must be such that jurisdiction depends upon the presence of a res. Analogous to the preceding situation, assumption of jurisdiction would prove merely that the domicil of the holder is a proper, although not necessarily the exclusive situs; whereas rejection of jurisdiction would demonstrate that the location of the bonds controlled, and that the domicil of the holder is insufficient to give a court jurisdiction. Gilmore $\approx$. Robillard substantially hits this situation. ${ }^{8}$ There the bonds and other securities were in New York. Complainant brought an action in the federal district court in California. the nonresident defendant being served under the federal constructive service statute. ${ }^{10}$ The district court sustained defendant's motion to quash. In the circuit cuurt of appeals complainant relied upon the doctrine that the situs of pursonal property is at the domicil of the owner, and maintained that the domicil of the testatrix, to whom the securities had belonged, was California. ${ }^{11}$ In affirming the judgment the court stated that the doctrine advanced by the complainant may be the rule where the question concerns taxation or the assumption of probate jurisdiction.

"but a different principle applies where the jurisdiction of a court over the persons of the defendants depends upon the fact that there is a res within the jurisdiction which may be reduced to possession by the court and disposed of by its judgment or decree." i2

Although the lone authority of Gilmore z: Robillard held that situs depended upon the presence of the bonds; a study of the decisions in which both elements, i.e., the bonds and the holder's domicil. are either present or absent, is necessary to discover which of these two elements will prevail to determine the basis of jurisdiction.

Actually, in three cases where suit was brought at the domicil of the holder and the bonds were present, the courts assumed jurisdiction in rem. ${ }^{13}$ But in none of these cases did the courts attach any significance to the domicil of the holder despite the fact that the holders appeared

9. 44 F. (2d) 295 (C. C. A. 9 th, 1930).

10. 36 StAT. 1102 (1911), 28 U. S. C. $\$ 118$ (1927).

11. Although the owner of the legal title was really the executor, the case was argugd and decided upon the assumption that the domicil of the testatrix was the domicil of the owner. Hence, the erroneous concept of ownership should be corerloolsed in evalusting the decision.

12. Gilmore v. Robillard, 44 F. (2d) 295,296 (C. C. A. 9 th, 1930).

13. Bede Steam Shipping Co. v. New York Trust Co. 54 F. (2d) 658 (S. D. N. Y. 1931) (United States certificates of indebtedness); First Trust Co. of St. Paul v. Matheson, 187 Mínn. 468, 246 N. W. 1 (1932); Laughlin v. Wells Bldg. Co., 169 WVis. 50, 171 N. W. 755 (1919). But cf. Cleveland National Bank v. Burroughs Land Co., 10 Ohio App. 61 (1917), which is distinguishable. 
as plaintiffs. ${ }^{14}$ On the contrary, the presence of the bonds was regarded as the determining factor.

Where both the domicil of the holder and the bonds are outside the state, the courts have refused to take jurisdiction in rem. ${ }^{15}$ With the exception of two Pennsylvania decisions, the courts, in rejecting jurisdiction, emphasized the absence of the bonds rather than the nonresidence of the holder. ${ }^{16}$ Thus Pennsylvania stands in solitary grandeur upon the other side of the fence. ${ }^{17}$ But the earlier of the two Pennsylvania cases should be treated sympathetically, because in 1876 the doctrine mobilia sequuntur personam was still "riding high." Nevertheless, the later case overlooked the modern concept of the bond itself as the res rather than mere evidence of the res, and adhered to the remnants of the aforementioned doctrine treating the debt as the res, the situs of which followed the owner. Yet perhaps censure of the decision should be softened by reason of the court's alternative ground that the relief sought was in personam in any event.

Naturally most of the cases turn upon their own peculiar fact situations, but it seems safe to conclude that the situs of the bonds themselves is the only situs for jurisdiction in rem over obligations evidenced by bonds. The opinion in First Trust Company of St. Paul v. Matheson ${ }^{18}$ expressed the soundness of this view in the following language:

"Evidences of debt though they are, yet the property represented, and all rights of ownership, so far inhere in the bonds that one in mere possession of them ordinarily has and may transfer title to all they represent as against the whole world . . .

"But when debtor and creditor create such a corporeal thing as bearer bonds, they have created something upon which jurisdiction of any kind may act. They have made more than mere symbol. They have fabricated a matrix-like container for the property, wherein it

14. This is not entirely clear in the Bede case, but if the holder was not the plaintiff, it was a trust company domiciled in the district.

15. See cases cited infra notes 16 and 17. Henderson v. Usher, 118 Fla. 688, 160 So. 9 (1935), is not contra, but reaches the opposite result by reason of the particular facts in the case.

16. Chase v. Wetzlar, 225 U. S. 79 (1912); Von Hesse v. Mackaye, 55 Hun 365, 8 N. Y. Supp. 894 (1st Dep't 1890) ; Hodgens v. Columbia Trust Co., 185 App. Div. 555, 173 N. Y. Supp. 304 (1st Dep't 1918) (based on absence of the bonds and nature of the relief demanded); Waverly v. Auditor of Public Accounts, 100 Ill. 354 (1881) semble; cf. McLaughilin v. McLaughlin Real Estate Co., 162 App. Div. 644, 147 N. Y. Supp. 959 (2d Dep't 1914). Williams v. Fischlein, 144 App. Div. 244, 129 N. Y. Supp. 129 (2d Dep't 1911), contains a pronouncement that the debt, being upon a specialty, namely, the bond, has its situs where the bond is. But then the court hedges by adding that at least where the creditor's domicil and the bond are both outside the state, the debt has no situs therein.

17. Huntzinger and Cake v. Philadelphia Coal Co., 11 Phila. 609 (Pa. C. P. 1876); Gallagher v. Rogan, 322 Pa. 315, 185 Atl. 707 (1936).

18. 187 Minn. 468,246 N. W. 1 (1932). 
is to be carried from place to place, jurisdiction to jurisdiction, at the will of the possessor. Mere manual transfer of the container transfers the property itself to new ownership. The property is so sealed in the container that he who has it must have the contents. In the practical sense, where the container is there also must be the property."19

Even at common law, bonds were considered personal property. Trover could be maintained for their conversion. They could be specifically replevied. They were looked upon as part of the movable estate of a deceased owner. ${ }^{20}$ How much more so should they be regarded today, when many states have made them subject to attachment; and, of even more importance, when the business community treats them as tangible personal property. ${ }^{21}$

\section{Bills, Notes and Checks}

With this background of the possible siti which might result from the refusal of courts to look upon the bond itself as property, the next question is to consider whether the courts regard the various forms of commercial paper as tangible property merging the obligation which they represent. If they do not, it is obvious that the case becomes one involving a simple debt. Whether a simple debt is property, and, if so, how to determine its situs, will be covered subsequently. ${ }^{22}$

From a logical standpoint, commercial paper, such as bills of exchange, drafts, promissory notes, and checks, should be placed in the same category with bonds; and its situs for jurisdiction in rem should depend upon the situs of the instrument itself. Commercial paper is transferable in the same manner as bonds and with the same effect: if bearer paper, it passes by delivery; if order, by indorsement and delivery; if the instrument is negotiable, it passes free from the so-called personal defenses; if nonnegotiable, it is subject to defenses. As in the case of a bond, most forms of commercial paper are regarded by the business world as more than the mere evidence of an indebtedness. The paper is looked upon as the embodiment of the underlying obligation.

In attempting to discover whether the courts have endowed commercial paper with a situs of its own, the authorities which have held or implied the affirmative will be considered first. They may be divided into two

19. First Trust Co. of St. Paul v. Mfatheson, 187 Jinn. 468, 473, 246 N. W. 1, 3 (1932).

20. See Von Hesse v. Mackaye, 55 Hun 365, 368, \& N. Y. Supp. 894,895 (1st Dep't 1890).

21. See First Trust Co. of St. Paul v. Mfatheson, 187 Minn. 468, 478, 246 N. W. 1, 3 (1932). The cases do not indicate whether the bonds must be negotiable, although in First Trust Co. v. Matheson the court pointed out that unregistered bearer bonds were involved.

22. See p. 254 et seq. infra. 
categories: first, those in which the instrument was outside the jurisdiction; and secondly, those in which the instrument was within the jurisdiction.

Decisions within the first of these classes are somewhat difficult to appraise, because in all of them the defendant in possession of the notes was a nonresident not subject to the court's personal jurisdiction. Under such circumstances it is natural to find in the decisions the idea that the want of jurisdiction is due to the absence of property and person. However, it seems fair to interpret these cases as holding or implying that if either the person or the instrument were within the jurisdiction of the court, it could hear the case. Jurisdiction over the nonresident holder would justify the court in entering an order against him with reference to the disposition of the instrument. Jurisdiction over the instrument would permit a decree concerning rights or interests in it, so long as the decree did not compel action upon the defendant's part. Although the cases are not wholly satisfactory, there runs through them the notion that absence of the paper prohibits jurisdiction in rem; and there is little or no intimation that the situs of the res is at any place other than the situs of the paper. ${ }^{23}$ But in effect the sum of all that the cases, in this category, would say is merely that if the document were within the state or district, the court would have jurisdiction. However, more positive authority in favor of the separate situs principle is found in those decisions which have upheld constructive service where the instrument was actually within the jurisdiction; for several cases have directly held that commercial paper constitutes property, the situs of which inheres in the paper. and the presence of which authorized constructive service upon a nonresident defendant. ${ }^{24}$

23. Bank of Jasper v. First National Bank of Rome, 258 U. S. 112 (1922) ; Beach v. Mosgrove, 16 Fed. 305 (C. C. D. Neb. 1883) (alternative ground of decision); Hauf v. Wilson, 31 Fed. 384 (C. C. W. D. Tenn. 1887) (in which the court said, "He is not here, nor the note") ; Pensacola State Bank v. Thornberry, 226 Fed. 611 (C. C. A. 6th, 1915) (intimation that situs is place where note is or where legal holder is, but perhaps court meant that in latter situation jurisdiction would be in personam rather than in rent); Gilmore v. Robillard, 44 F. (2d) 295 (C. C. A. 9th, 1930) (treating note in same category as bond, without comment) ; Tigrett v. Taylor, 180 Ala. 296, 60 So. 858 (1912); Ward v. Boyce, 152 N. Y. 191, 46 N. E. 180 (1897) (alternative ground of decision); Hodgens v. Columbia Trust Co., 185 App. Div. 555, 173 N. Y. Supp. 304 (1st Dep't 1918).

24. Manning v. Berdan, 132 Fed. 382 (C. C. D. N. J. 1904) ; Jones v. Rutherford, 26 App. D. C. 114 (1905); Loaiza v. Superior Court of San Francisco, 85 Cal. 11, 24 Pac. 707 (1890) ; Doepke v. Christy Box Car Loader Co., 14 Ohio N. P. (N. s.) 523, 26 Ohio Dec. (N. P.) 583 (C. P. 1913). Although in the Loaiza case the payee of the notes was in California and personally served, he was merely the agent of the nonresident defendants, and the court based its decision upon the presence of the notes. Three cases rejecting jurisdiction despite the presence of the paper were decided upon special grounds and are not contra to the rule. Crichton v. Wingfield, 258 U. S. 66 (1922) 
In the Manming case, for example, defendant's counsel argued that the note was not personal property within the constructive service statute, but was a mere written promise and evidence of a debt. To this contention the court replied that the promissory note was more than a mere written promise; that it was a negotiable instrument, recognized by the law merchant as property; that a transfer of the note operated as a transfer of the debt; and that the note should be regarded the same as a bond.

It is interesting to observe that the decisions holding that commercial paper is property and possesses a situs of its own do not stress the negotiability of the instrument. In fact, in many of the cases cited, ${ }^{23}$ it is not shown whether the instrument was negotiable or nonnegotiable; and in those in which it does appear that the instrument was negotiable, the court barely mentions the fact.

It is now appropriate to examine the authorities holding or leaning toward the view that commercial paper is not property separate and apart from the underlying obligation, and does not have a situs of its own. In two of the cases in which the court rejected jurisdiction, the notes were outside the state. This would render these cases consistent with the view that the paper does have a separate situs, but for the fact that the decision in one was upon the theory that a debt has its situs where the creditor is, ${ }^{26}$ and that in the other, the IFilliamson case, the court seemed opposed to the idea that a note in itself is property. ${ }^{27}$ However, in First Trust Company of St. Paul 'i. Mathcson, ${ }^{23}$ which, as indicated above. held that bonds have their own situs, the court distinguished the IVillianson case upon the ground that there no property was within the state. Yet in two cases, notwithstanding the presence of the document, the court rejected jurisdiction, partially at least, although somewhat vaguely, because of the theory that the document has no separate situs. $\$$

The most direct authority refusing to confer a separate situs upon commercial paper is First National Bank of Brolen Boa' '. Bank of

(notes brought into state wrongfully); Winnett Times Publishing Co. v. Berg, \&2 Mont. 141, $265 \mathrm{Pac} 710$ (1928) (action in personam); American Soda Fountain Co. v. Hairston Drug Co., 52 S. W. (2d) 764 (Tex. Civ. App. 1932) (action is personam).

25. See cases cited supra notes 23,24 .

26. J. L. Cocke \& Co. v. Brewer, 68 Miss. 775, 9 So. $\$ 23$ (1891).

27. Williamson v. Falkenhagen, 178 Minn. 379, 227 N. W. 429 (1929). An investigation of the decisions relied upon in that case leads to the opinion that the court meant to decide the case upon the dual grounds that the action was in persos:am and that a debt evidenced by a note is a mere chose in action or personal chattel.

28. 187 Minn. 468,246 N. W. 1 (1932).

29. Larson v. Dubuque Fire \& دiarine Ins. Co., $23 S$ Mich. 365, 213 N. W. 140 (1927) ; Warlick v. Reynolds, 151 N. C. 606,66 S. E. 657 (1910) (counsel did not raise proposition that presence of notes gives jurisdiction). 
Horatio. $^{30}$ But there the certificates of deposit were nonnegotiable, and the court stressed this feature in reaching its conclusion. ${ }^{31}$

From a review of the authorities, the following conclusion may be drawn: that generally negotiable instruments are regarded as property apart from the obligations for which they are given, and that the clocuments themselves have a situs of their own after the manner of tangible personalty. The underlying obligation becomes merged in the paper, and is no longer a res, if indeed it ever was, with a situs of its own. As to nonnegotiable paper the law is not so clear. Yet for the purpose of situs, it should be treated the same as negotiable paper. ${ }^{32}$ The underlying obligation is as completely merged in a nonnegotiable as in a negotiable instrument. That a remote holder of the nonnegotiable instrument takes subject to more defenses than does the holder of a negotiable instrument is no argument in favor of nonmerger. A negotiable instrument, payable to order, may be transferred without indorsement, in which case the transferee takes subject to all defenses; but no one would contend that this prevents the negotiable instrument from being a res separate and apart from the underlying debt. The inferior position of the innocent purchaser for value should not be held to differentiate the nonnegotiable from the negotiable instrument so far as its status as a res is concerned.

\section{Insurance Policies}

Professor Beale, in his monumental work on Conflict of Laz's, supplies a proper starting point for this investigation. He states:

"Whether an insurance policy is to be treated as a chattel for purposes of jurisdiction remains doubtful on the authorities." 3

He cites on this proposition only one case $;^{34}$ and although the court's language there leaves one in doubt as to the exact meaning intended,

30. 161 Ark. 259, 255 S. W. 881 (1923) (court permitted cancellation of assignment of certificates of deposit, notwithstanding absence of certificates and assignee; treated deposit as res). Accord: Standard Dredging Co. v. Title Insurance \& Trust Co., 96 Cal. App. 93, 273 Pac. 871 (1928). The latter case appears contra to the Loaiza case cited supra note 24 , unless the notes in the Loaiza case were negotiable. The Standard Dredging Co. case does not refer to the Loaiza decision. Another possible distinction arises from the fact that the so-called notes in the Standard Drcdging Co. case were subject to certain conditions, which, under familiar principles of bills and notes, would prevent their being notes at all. This point, however, the court did not notice, treating the instruments as nonnegotiable notes.

31. A dictum in Steger v. Shofner, 54 S. W. (2d) 1013, 1016 (Tex. Civ. App. 1932), to the effect that under the law of Texas promissory notes and checks have no situs independent of the owner's domicil is weakened by the court's failure to citc a single authority.

32. A contrary view, unsupported by argument, is expressed in (1929) 38 Y ALE L. J. 394.

33. 1 Beale, Conflict of Laws (1935) 446.

34. Evans v. Charles Scribner's Sons, 58 Fed. 303 (C. C. N. D. Ga. 1893). 
the opinion, taken as a whole, seems to indicate that the court does not consider an insurance policy property in the sense of the constructive service statute. But there are a number of other decisions at least touching the question. Whether they will dispel the doubt expressed by Professor Beale remains to be seen.

It has been held that jurisdiction in rem cannot be founded upon the mere presence of an insurance policy. ${ }^{35}$ And although in sereral cases the court at the place where the policy was located did assume jurisdiction, a careful study of the opinions in these cases reveals that the presence of the policy was not the controlling factor. ${ }^{30}$ Two cases are of such importance that they require detailed discussion. ${ }^{37}$

In the Cameron case, the policy named the sisters of the insured as beneficiaries. After the insured's death, his widow brought an action in New Jersey to reform the policy, claiming that by mistake the beneficiary clause omitted a provision making the insured's wife the beneficiary should she survive the insured. Plaintiff had possession of the policy. There was jurisdiction in personam over the insurance company and one sister. The other sister was served by publication. She appeared specially, challenging the jurisdiction. The court denied her motion, and ruled that the service by publication constituted due process, since the proceeding was quasi in rem, and the policy, the res against which the decree of reformation would become effective, was in the possession of the complainant and within control of the court.

"Such a decree," continued the court, "as to this defendant, will affect only the policy by determining its form and will not be dispositive of her claim thereunder." 38

This reasoning seems rather specious, because after the reformation complainant would be the beneficiary and thus entitled to the proceeds of the policy. In deciding to reform the policy, the court ipso facto must have passed upon and decided adversely to the sister the facts constituting the basis of her claim, namely, the intended contents of the beneficiary

35. Stockbridge v. Phoenix MIutual Life Ins. Co., 193 Fed. 558 (D. Conn. 1912) (stating that the policies do not constitute property); Austin v. Royal League, $316 \mathrm{III}$. 18S, 147 N. E. 106 (1925). In MFahr v. Norwich Union Fire Ins. Society, 127 N. Y. 452, 28 N. E. 391 (1891), counsel conceded the point.

36. Bank of Idana v. Illinois Lifel Ins. Co., $135 \mathrm{Kan} .129,9$ P. (2d) 629 (1932); Morgan v. Mutual Benefit Life Ins. Co., 189 N. Y. 447, $\$ 2$ N. E. 438 (1907); Cutter v. American Trust Co., 213 N. C. 686, 197 S. E. 542 (1938). Ely v. Hartford Life Ins. Co., $128 \mathrm{Ky} .799,110$ S. W. 265 (1908), an interpleader action, placed considerable emphasis upon the presence of the policy, but is opposed to the general rule in interpleader cases. See Chafee, Interstate Interpleader (1924) 33 YaLe L. J. 685, 714, n. 102.

37. Perry v. Young, 133 Tenn. 522, 182 S. W. 577 (1916); Cameron v. Penn Mrutual Life Ins. Co., 111 N. J. Eq. 24, 161 Atl. 55 (1932), petition to set aside decree and relitigate question of jurisdiction denicd, with opinion, 116 X. J. Eq. 311, 173 Atl. 344 (1934).

38. Cameron v. Penn Mitual Life Ins. Co., 111 N. J. Eq. 24, 26, 161 Atl. 55, 57 (1932). 
clause. Although possibly a second court, having jurisdiction in personam of the sister, might hold that the first court lacked jurisdiction and that its decree was therefore not entitled to full faith and credit and not res judicata as to the facts determinative of the reformation, it is also possible that the second court might decide, even though erroneously, that the first court had jurisdiction. In this event the second court would render judgment against the sister, and, since by hypothesis, it had jurisdiction, her claim would be forever cut off.

An even more peculiar line of argument was advanced by the court in a subsequent part of the opinion, namely, that if the contract was as alleged in the bill, defendant had no rights under it, and, as a result, reformation would not deprive her of any property without due process of law. Under this fallacious theory a court would always have the right to decicle the controversy on its merits, regardless of jurisdiction over the defendant.

Neither of the two reasons just given seems worthy of serious thought. But another, and, indeed, the main ground for the decision, requires closer study. The court, after saying that a proceeding to reform a written instrument is usually in personam, added that actions to reform deeds are held in rem or quasi in rem.

"Such actions may be in personam as to the parties to the contract or instrument sought to be reformed; but as to third parties, whose rights are incidental only, and depend upon what the contract in fact is, not upon what it appears to be, the suit is quasi in rem. It is possible for an action to be in personam as to one defendant and quasi in rem as to another." 39

The court then concluded that the principle in the case before it was the same as in actions to quiet title to lands within the state.

With the general principle that an action to reform a contract is in personam, no one will disagree. ${ }^{40}$ Nor is there any denying the correctness of the proposition that actions to reform deeds and other conveyances of land may be in rem. ${ }^{41}$ But they are in rem not because the written instrument itself is a res, but because it affects the interests of the parties in the land, which is the res.

When the Cameron litigation arose a second time, on defendant's petition to reopen the case, set aside the decree, and relitigate the question of jurisdiction, defendant contended that at the time of the original suit the policy was not in New Jersey, but was in possession of the insurance company in Pennsylvania. In refusing to reconsider the case, the court called attention to a stipulation in the original suit, by which counsel admitted the presence of the policy. In the opinion of the vice-

39. Cameron v. Penn Mutual Life Ins. Co., 111 N. J. Eq. 24, 28, 161 Atl. 55, 57 (1932).

40. See (1933) 42 YALE L. J. 285.

41. Ibid. 
chancellor this stipulation precluded a rehearing. But he went on to say that jurisdiction existed even in the absence of the policy, because through control over the company and complainant, the policy could be obtained. To use the vice-chancellor's words,

“. . . the test of jurisdiction is not the physical presence of the policy itself within the borders of the state. If it is potentially within the court's control, that is sufficient." 12

This theory is inconsistent with the conception of an in ren or quasi in rem proceeding, each of which requires that the property be within the state.

In the second of these two cases, Perry a. Young, ${ }^{33}$ the insured assigned the policy to his mother, who later died. The distributees of the mother's estate were then in the position of the mother so far as concerned any right in the policy. The insured brought an action to reform the assignment agreement by inserting a provision that, in the event of his mother's prior death, the policy was to revert to him. He claimed that this provision had been omitted from the assignment through oversight. Plaintiff brought the action because he wished to borrow on the policy, and the company refused to accede to his request without the consent of the distributees. The insurance company and some of the distributees were subject to the personal jurisdiction of the court; but one of the distributees was not so subject and was served by publication. The court upheld the constructive service.

The fact situations in the Perry and Cameron cases should be compared. In the Cameron case the action was to reform the policy, and thus by no means could be considered as one directly affecting property; in the Perry case the action sought to reform an assigmment of the policy. Thus, if the policy be considered property, the case is parallel to an action to reform a deed to real property, and the controversy concerns a dispute over the ownership of the property itself. This is the perfect factual situation for the determination of the question. Is the insurance policy to be treated as property, the assignment of which constitutes a transfer of property; or is it to be treated as a simple contract, the assignment of which affects no property because nothing but the contractual rights or liabilities are assigned?

The opinion of the court in the Perry case is not entirely satisfactory. The court said that it had the insurance company before it, that it had within its control the policy and the assignment on the back of it, and ". . . the res itself, the claim against the insurance company through having the latter company before it." 14

42. Cameron v. Penn Miutual Life Ins. Co., 111 N. J. Eq. 311, 314, 173 Atl. 344, 346 (1934).

43. 133 Tenn. 522, 182 S. W. 577 (1916).

44. Perry v. Young, 133 Tenn. 522, 525, 182 S. W. 577, 578 (1916). 
This would indicate that the court regarded the obligation of the company, rather than the policy, as the res. ${ }^{45}$ However, the court goes on to state that, although the policy is not actually in court, it may be obtained from the plaintiff at any time.

"The court, thus having control of the res, can settle the status and rights of the parties with respect to the insurance policy, although one of the persons interested therein, under the assignment as it now stands, is a nonresident, and made a defendant only by publication." ${ }^{46}$

Does this sentence mean that the policy, rather than the claim against the insurance company, is the res? The answer would appear to be in the negative; that, taken as a 'whole, although control of the policy is necessary in order to reform it, the res is not the policy, but is the claim against the insurance company.

Two judges, however, dissented, upon the ground that there was no property or res in the state, and that the action was entirely personal. Judge Fancher, one of the dissenters, argued that a policy of insurance is not property, but is only evidence of an obligation, and that the obligation itself "is like a thing in the air which may fly anywhere." 47

The Perry case has not enjoyed much popularity, ${ }^{48}$ and, because it named the claim against the insurance company as the res, it cannot be regarded as authority for the proposition that the policy is the res. Similarly, Evans v. Charles Scribner's Sons ${ }^{40}$ contained language seemingly against the concept of the insurance policy as a res. Other cases contain similar language or language so ambiguous as to render it impossible for use even as dictum. ${ }^{\text {.0 }}$

45. Confusion is added by reason of the fact that no claim against the company existed at the time, since the insured still lived.

46. Perry v. Young, 133 Tenn. 522, 526, 182 S. W. 577, 578 (1916).

47. Perry v. Young, 133 Tenn. 522, 541, 182 S. W. 577,582 (1916). To buttress his position, Judge Fancher erroneously likened a policy of insurance to a note, which, as we have already seen, is considered property, at least if negotiable.

48. Edwards v. New York Life Ins. Co., 173 Tenn. 102, 114 S. W. (2d) 808 (1938), discusses Perry v. Young. And see Note I.R.A. 1917 B 393.

49. 58 Fed. 303 (C. C. N. D. Ga. 1893).

50. Vogel v. New York Life Ins. Co., 55 F. (2d) 205 (C. C. A. 5th, 1932), cert. denied, 287 U. S. 604 (1932) (situs of policies as choses in action said to be domicil of debtor) ; McBride v. Garland, 89 N. J. Eq. 314, 104 Atl. 435 (1918) (inconclusive; distinguished in the Cameron case); Taylor v. Security Mutual Life Ins. Co., 38 Misc. 575, 77 N. Y. Supp. 1012 (Sup. Ct. 1902) (wherein the court apparently overiooked the necessity that any property be present); Gleason v. Northwestern Mutual Life Ins. Co., 203 N. Y. 507,97 N. E. 35 (1911) (language ambiguous); Edwards v. New York Life Ins. Co., 173 Tenn. 102, 114 S. W. (2d) 808 (1938) (inconclusive); Atlas Life Ins. Co. v. Standfier, 86 S. W. (2d) 852 (Tex. Civ. App. 1935) (inconclusive); Riedel v. Northwestern Mutual Life Ins. Co., 211 Wis. 149, 246 N. W. 569. (1933) (inconclusive). The Supreme Court of the United States has held that a suit by an insurance company to cancel a policy "did not concern any property, real or personal." New York Life Ins. 
But one thing seems certain regardless of the Cameron decision. Unless the action concerns conflicting claims to the policy as property, constructive service should not be sufficient. Thus, actions to cancel or reform the policy should be regarded as in personam. But where a situation exists in which $A$ and $B$ each claims to own the policy, or in which reformation of an assignnent is sought, constructive service is permissible if the policy be regarded as property. That it is so regarded is certainly not settled. Until there is more definite authority treating an insurance policy as a res, one is forced to the conclusion that it is placed in the same category as an ordinary contract, which is not considered a res for purposes of constructive service. ${ }^{51}$

\section{Funds}

The majority rule is that "funds" in the hands of administrators," trustees, ${ }^{53}$ or receivers ${ }^{54}$ are regarded as property under constructive service statutes. The same has been held of the proceeds of a special tax levy. ${ }^{55}$ From a realistic point of view there is generally no actual fund, in the sense of specific money, in the possession of the administrator or other fiduciary. Usually he has a bank account in his name as administrator, and the so-called "fund" is nothing more or less than the amount on deposit to his credit in the bank. Likewise, a bank or trust company acting as trustee does not ordinarily hold any specific money to represent the amount credited to the trust account. Yet to regard such

Co. v. Bangs, 103 U. S. 435 (1880). This is no authority on our point, however, bseause the nature of the action was clearly not in rem.

51. See Steger v. Shofner, 54 S. W. (2d) 1013 (Tex. Civ. App. 1932); cf. Iron Age Publishing Co. v. Western Union Telegraph Co., 83 Ala. 498, 3 So. 449 (188s); Law:rence v. Times Printing Co., 90 Fed. 24 (C. C. D. Wash. 1898).

52. Goodman v. Niblack, 102 U. S. 555 (1SSO) (lien on amount paid to administrator in satisfaction of judgment); Castello v. Castello, 14 Fed. 207 (C. C. IV. D. Alo. 1882) (removal of cloud on title to estate which has been converted into money).

53. Dahlgren v. Pierce, 263 Fed. S41 (C. C. A. 6th, 1920) (testamentary trust under administration of court; accrued income); Spellman v. Sullivian, 43 F. (2d) 762 (S. D. N. Y. 1930) (jurisdiction over trust company and trust corpus; surplus income); Blauner v. Hirsch, 57 F. (2d) 114 (C. C. A. 6th, 1932) (rental money paid to trustee of lease) ; Standard Dredging Co. v. Title Insurance \& Trust Co., 96 Cal. App. 93, 273 Pac. 871 (1928) ("fund" deposited in trust company as collateral); see National Eank: of New Jersey v. White, 93 N. J. Eq. 109, 110, 115 Atl. 533, 534 (1921); cf. Bede Steam Shipping Co. v. New York Trust Co., 54 F. (2d) 658 (S. D. N. Y. 1931); Mcllurray v. Chase National Bank, 10 F. Supp. 960 (D. Wyo. 1935); Coyne v. Plume, 90 Conn. 293, 97 Atl. 337 (1916); Chappell v. Clarke, 94 Mrd. 178, 50 Atl. 527 (1901). Pollitz v. Farmers' Loan and Trust Co., 39 Fed. 707 (C. C. S. D. N. Y. 18S9), also recognizes the principle and holds that there is jurisdiction to enjoin a trustee from paying a sum of money to a nonresident constructively served.

54. Brown v. Pegram, 143 Fed. 701 (C. C. E. D. Pa. 1906) (removal of cloud on title).

55. Continental Trust Co. v. Shunk Plow Co., 263 Fed. 873 (C. C. A. 5th, 1920). 
"funds" as a res is a convenient, useful, and not illogical fiction. Oddly enough, the courts take the rule for granted, and no detailed discussion of its basis has been found. Of course, one might put it upon the ground that the estate and all its local assets, including bank accounts, are in custodia legis. But this does not explain the federal cases, for in them the estate is not in the custody of the federal court, but of the proper state court. However, it is not unreasonable to take the position that an estate under the supervision of the state court within a given county or district has a local situs, and consequently that all local property belonging to the estate, including bank accounts, is property within the county or district.

Not all the cases, however, concern property under the supervision of a court through an administrator, trustee, or the like. For instance, in Blauner $v$. Hirsch ${ }^{56}$ a ninety-nine year lease was assigned to a trust company as trustee, and nothing in the report indicates that the trust was under judicial supervision. Regardless of this, and without mentioning it, the court held that the rentals paid into the trust company constituted a res. In addition to pointing out that the rentals grew out of real estate, the court states that, apart therefrom, the presence of the trust company and the trust res sufficed to give the court authority to determine the relative rights of parties in the trust res. It is worth noting that the trust company in Blauner v. Hirsch was a New York company, but it maintained a branch in Cleveland, and this branch handled the trust which was the subject-matter of the suit. In all the cases cited there was a localization of the res by reason of either judicial supervision over the estate, trust, or receivership, or jurisdiction over the trustee, which in itself was localized in that it was a bank or trust company, domiciled or carrying on its business in the state or district. In the cases of the latter type, the units comprising the trust, whether tangible or intangible. were under local management.

\section{Debts}

Is a debt property of the sort required for constructive service? If so, how does one determine its situs?

It is difficult to conceive of a debt as property in the ordinary sense of the word. If $A$ owes $B$ a thousand dollars, may it be said that $B$ owns any specific property? If $B$ assigns the claim to $C$, is $B$ transferring to

56. 57 F. (2d) 114 (C. C. A. 6th, 1932). A similar situation was present in Standard Dredging Co. v. Title Insurance \& Trust Co., 96 Cal. App. 93, 273 Pac. 871 (1928). In Mutual Home Association v. Zwatchka, 297 S. W. 317 (Tex. Civ. App. 1927), the court took the same position with reference to a deposit by the nonresident defendant in a local bank, plaintiff claiming that the deposit was made to secure a note executed by the nonresident. But query whether the court was correct. Perhaps the decision may be approved upon the basis that a special deposit should be considered a res. 
$C$ an interest in any property? If there is a dispute as to the validity of the assignment, is $A$, in suing $B$ and making $C$ a party; asking the court to decide that $B$ owns specific property; or is he asking the court to decide that $A$ owes the thousand dollars to $B$ instead of to $C$ ?

To constitute property within the constructive service statutes the res must be capable of having a situs. How can a debt have a situs? A debt is merely an obligation upon the part of the debtor to pay the given amount to the creditor upon the due date.

The problem is by no means simplified by other types of action wherein the situs of a debt has been at issue. For example, for purposes of jurisdiction to tax, it has been held that debts have a situs at the domicil of the creditor, ${ }^{58}$ whereas for purposes of administration of an estate the domicil of the debtor is the situs. ${ }^{59}$ Likewise, since Harris $a$. Balls, ${ }^{69}$ a debt may be garnished wherever plaintiff is able to get jurisdiction over the debtor. Consistently with the garnishment cases, perhaps a debt should be held a res, the situs of which travels with the debtor. Yet as Professor Beale has said, ${ }^{\text {i1 }}$

“. . . the notion that garnishment is an ordinary action against the garnishee in combination with another personal action, an action against the principal debtor, has led the courts gradually to decide that garnishment proceedings will lie in any place in which personal jurisdiction may be obtained over the garnishee. In short, the original conception of garnishment as a proceeding based on jurisdiction in rem orer a thing has been entirely superseded by a conception of garnishment as a transitory personal action against the garnishee."

That the garnishment cases have lost sight of the in rem nature of the proceeding is no reason for duplicating the error in conflicting claim cases, which by constitution and statute require the presence of property within the jurisdiction. ${ }^{62}$ Furthermore. consistency is not a sine qua non in the development of the law, and in order to find the answer to the immediate question, it will be more prudent to observe only the conflicting claimant cases and let garnishment shuffle for itself. Besides. perhaps consistency demands with equal logic that the conflicting claim situation

57. See Comments (1917) $30 \mathrm{HARr}$ L. REv. 4\$6, (1926) $39 \mathrm{HLAN}$. L. REw. 485, maintaining that a debt is incorporeal and incapable of having a situs.

58. See 1 Beale, loc. cit. supra note 4 .

59. See Wyman v. Halstead, 109 U. S. 654, 656 (18S4).

60. 198 U. S. 215 (1904).

61. Beale, The Exercise of Jurisdiction in Ren to Compel Payment of a Dcht (1913) 27 HART. L. Rev. 107, 118.

62. For a good statement of the essential difference between situs in garnishment and situs in conflicting claim cases, see Yon Hesse v. Mfachaye, 55 Hun $365,369,8$ N. Y. Supp. 894, 896 (1st Dep't 1890). Sce also Bank of Jasrer v. First National Banl: of Rome, Georgia, 258 U. S. 112, 119 (1922). 
be decided in the same manner as the interpleader cases, the majority of which do not permit constructive service. ${ }^{63}$

In considering the authorities on this issue, i.e., whether or not a debt is property in a suit brought by $A$, claiming that he is entitled to or has an interest in the amount due, and seeking to bar $B$, a nonresident, from some interest therein, it will be convenient to look first at the federal cases. Two Supreme Court decisions must be scrutinized. The first; in point of time, is Baker v. Baker, Eccles \& Company. ${ }^{64}$ Decedent's widow brought an action in Tennessee, claiming that decedent was domiciled there, by reason of which, under Tennessee law, complainant was entitled to all the personalty. Among the assets was a claim against a Kentucky corporation. If Kentucky was decedent's domicil, his mother would share equally with his widow. The mother, a nonresident of Tennessee, was served by publication. The Tennessee court held that Tennessee was the domicil and, as a consequence, decreed that the widow owned all the personal property. In a subsequent suit in Kentucky, the court refused to give full faith and credit to the Tennessee decree so far as it affected the claim against the Kentucky corporation. The Supreme Court upheld the Kentucky court upon the theory that the Tennessee decree could have no effect in rem upon the Kentucky assets. It might logically be deduced from this holding that the Supreme Court meant that a debt is property at the domicil of the debtor, and that an action to determine ownership of the debt may properly be brought in that state. However, a study of the opinion indicates that the court intended to hold only that, for purposes of founding administration, simple contract debts are assets at the domicil of the debtor. Such a limited holding would suffice to decide the case, for if the debt constituted an asset of the estate in Kentucky, that state alone would possess the power to determine its distribution. Indeed, if such a limitation is not placed upon the decision, it conflicts with the more recent opinion of Mr. Justice Brandeis in Bank of Jasper v. First National Bank of Rome, Georgia. ${ }^{65}$

63. See Chafee, Interstate Interpleader (1924) 33 YALE L. J. 685. As Professor Chafee points out at page 699 of his article, since a state would have jurisdiction over a nonresident in interpleader actions relating to land or chattels, the reason for not allowing interpleader in the debt cases must be that the courts do not regard a debt as property. Apparently the Federal Interpleader Act, 49 STAT. 1096, 28 U. S. C. A. $\$ 41$ (26) (Supp. 1938), does not affect conflicting claimant actions brought under the constructive service statute, 36 STAT. 1102 (1911), 28 U. S. C. $\$ 118$ (1927); and Rules 4 (e) and 4 (f), Fed. Rules Civ. Proc. (1938), merely enlarge the in personam territory of the United States District Courts. Cf. New York Life Insurance Co. v. Dunlevy, 241 U. S. 518 (1916).

64. 242 U. S. 394 (1917).

65. 258 U. S. 112 (1922). Although technically dictum, Justice Brandeis' opinion that an indebtedness on open account is not such property as to permit constructive service is of great importance, since it appears to be the only pronouncement by the Supreme Court on the exact point. 
Two district court cases, decided before either of the Supreme Court cases just discussed, take the view that a general indebtedness is not a res within the meaning of the constructive service statute. ${ }^{\mathrm{GS}}$ Directly opposed to that view is a more recent decision of the Circuit Court of Appeals for the Eighth Circuit, ${ }^{67}$ holding that constructive service is authorized under the federal statute in an action involving conflicting claims to a bank credit. Plaintiff claimed that the transfer of the credit should be declared fraudulent and void and the amount thereof paid to plaintiff. After commenting upon the position of one defrauded of his property, the court said:

"Impliedly conceding, for sake of argument, all that has been said, it is contended that the facts pleaded show only a paper transaction, which did not create or bring under the court's jurisdiction any personal property within the meaning of Section 118, that the section contemplates some specific tangible thing, that here no money passed, no particular fund was created, only book entries were made at plaintiff's direction in the Omaha Branch bank, and there is no res in the State and district of Nebraska which can be adjudged upon and disposed of by the court. It would be hard to convince men who devote their time to business and financial transactions that there is any merit in the contention. As proof to the contrary, and as a matter of common knowledge, the $\$ 60,000$ will be handed over at the Branch bank's counter on proper orders to him who is entitled to it. In every practical and business sense the $\$ 60,000$ is there, and it is a sacrifice of substance to form to say it is not. For remedial purposes on plaintiff's bill we think the situs of any property interest in the transferred deposit was at Omaha." 68

The court then concluded:

"Accepting the allegations as stating the true facts, we think the $\$ 60,000$ transferred to the credit of Wyoming National Bank in the Omaha Branch bank was personal property within the court's jurisdiction, to which plaintiff asserted an equitable claim and title, and in that respect the suit was one properly brought under Section 118." $" 99$

Oddly enough, the court cited the Bank of Jasper case, which, as already indicated, contained a dictum to the opposite effect. The court

66. Stockbridge v. Phoenix Míutual Life Ins. Co., 193 Fed. 558 (D. Conn. 1912) (claim against insurance company); Murphy v. Ford Motor Co., 241 Fed. 134 (S. D. Ohio 1916).

67. Omaha National Bank v. Federal Reserve Bank of Kansas City, 26 F. (2d) 884 (C. C. A. Sth, 1928), cert. denied, 278 U. S. 615 (1928).

68. Omaha National Bank v. Federal Reserve Bank of Kinsas City, 26 F. (2d) 884, 887 (C. C. A. Sth, 1928).

69. Omaha National Bank v. Federal Reserve Bank of Kansas City, 26 F. (2d) $\$ 84,889$ (C. C. A. 8 th, 1928). 
also cited Goodman v. Niblack, ${ }^{70}$ which dealt with money in the hands of an administrator, a distinguishable situation. Unless an inherent difference exists between a debt due from a bank and a debt due from an insurance company or some other kind of obligor, the Omaha National Bank case must be classified as contrary to the earlier federal decisions. The mere fact that the bank may ordinarily be sued in only one jurisdiction, whereas the insurance company or other debtor may often be subject to suit in several places, is no reason for holding that what was not property in the latter case underwent a metamorphosis in the former. ${ }^{71}$ It must be acknowledged, then, that a difference of opinion exists among the federal authorities and that the point is far from settled.

Likewise, the state courts have disagreed. A number of cases upheld constructive service in actions relating to the ownership of a debt. ${ }^{72}$ In

70. 102 U. S. $556(1880)$.

71. Thompson v. Terminal Shares, Inc., 89 F. (2d) 652 (C. C. A. 8th, 1937), reaches the same result as the Omaha National Bank case in a suit involving debts owing by Missouri corporations. But the constructive service took place under the Missouri statutes, so that theoretically, at least, the decision should be placed with the Missouri cases. As to whether a claim against the United States has a situs at the seat of the Government, see Vaughn v. Northup, 15 Pet. 1 (U. S. 1841); United States v. Gorcherling, 185 U. S. 223 (1902) ; Roberts v. Consaul, 24 App. D. C. 551 (1905); Phillips v. Noel Construction Co., 266 Fed. 603 (App. D. C. 1920), cert. denied, 254 U. S. 631 (1920); Mellon v. Jones, 51 F. (2d) 431 (App. D. C. 1931), ccrt. denicd, Jones v. Mellon, 284 U. S. 641 (1931).

72. First National Bank of Broken Bow v. Bank of Horatio, 161 Ark. 259, 255 S. W. 881 (1923) (bank deposit; court called it a fund; nonnegotiable notes involved, but decision was without reference to them); Michigan Trust Co. v. Probasco, 29 Ind. App. 109, 63 N. E. 255 (1902) (concerned ownership of stock, but court treated it as debt, and held situs at domicil of "debtor" corporation) ; Ely v. Hartford Life Ins. Co., $128 \mathrm{Ky} .799,110 \mathrm{~S}$. W. 265 (1908) (full faith and credit to Ohio judgment on constructive service on insurance company's cross-bill; based upon presence of policy and presence of company) ; Thompson v. Terminal Shares, Iuc., 89 F. (2d) 652 (C. C. A. 8th, 1937) (involving Missouri constructive service statutes; debts of Missouri corporations); State ex rel. Richardson v. Mueller, 230 Mo. App. 962, 90 S. IV. (2d) 171 (1936) (attorney's lien on "moneys" due from insurance company); Taylor v. Security Mutual Life Ins. Co., 38 Misc. 575, 77 N. Y. Supp. 1012 (Sup. Ct. 1902) (in which, however, court seemed unaware of necessity of a res) ; Morgan v. Mutual Benefit Life Ins. Co., 189 N. Y. 447, 82 N. E. 438 (1907) (equitable lien claim against amount duce on insurance policy; a confusing opinion); Oishei v. Pennsylvania R. R., 117 App. Div. 110,102 N. Y. Supp. 368 (1st Dep't 1907), aff'd without opinion, 191 N. Y. 544, 85 N. E. 1113 (1908) (attorney's lien); McKennell v. Payne, 197 App. Div. 340, 189 N. Y. Supp. 7 (2d Dep't 1921) (attorney's lien; court said: "The controlling point is that the fund upon which the lien is asserted appears in the eye of the law to be here, although in fact we well know that it is not. This appears to be a case where the doctrine or convenience of a legal fiction still survives."); Kumor v. Scottish Union \& N. Ins. Co., 47 Wyo. 174, 33 P. (2d) 916 (1934) (claim against fire insurance company; court held "proceeds" of policy to be res; query whether presence of the insured property influenced the court) ; cf. Clark v. Brotherhood of Locomotive Firemen, 99 Mo. App. 687, 74 S. W. 412 (1903) (not a conflicting claimant case); State $e x$ rel. Reid v. Barrett, 118 S. W. 
states committed to this doctrine a collateral problem arises. Is the situs of the debt limited to the domicil of the debtor, or does it embrace all places where one may obtain personal jurisdiction over him? The latter appears to be the law. ${ }^{73}$ All the cases cited involved foreign corporations doing business in the state of suit. Under this rule a debt may have a situs in a number of places at the same time, which, from a strictly theoretical standpoint, seems illogical. From a practical standpoint, however, the situation is no worse than in any other case in which two or more courts have concurrent jurisdiction. Suppose, for example, that claimant $A$ sues the debtor in state $\mathrm{X}$, making nonresident claimant $B$ a party. Suppose that thereafter claimant $B$ sues the debtor in state $Y$, making nonresident claimant $A$ a party. It is possible that the court in state $Y$ will stay the proceedings, but suppose it refuses to do so. If the state $X$ court renders judgment, this will bar further proceedings in the state $Y$ court, which, by hypothesis, deems a debt property endowed with a migratory situs, and which, therefore, will give full faith and credit to the judgment. Of course, if state $Y$ happened to be among the group holding that a debt is not a res, its court would dismiss the original action and the present problem would not then arise. The only ticklish situation would come about if the debtor were domiciled in state $Y$, where the rule happened to be that a debt, although property, has no situs. except at the domicil of the debtor. Under these circumstances, state $Y$ would refuse to give full faith and credit to the state $\mathrm{X}$ judgment, and the only recourse would be to take the matter to the Supreme Court of the United States for a decision on the jurisdictional question of whether or not the debt constituted property with a situs in state $X$. The difficulty referred to is not in itself sufficient to overthrow the rule that the debt has a situs wherever the debtor is subject to personal jurisdiction. This is especially true, because among the courts holding that a debt is property for purposes of constructive service there appears to be no dissent from the above rule, in consequence of which the difficulty is unlikely to arise.

(2d) 33 (Mo. 1938) (confusing but probably based upon presence of land as res); Perry v. Young, 133 Tenn. 522, 182 S. W. 577 (1915) (action to reform an insurance poliey; court said res was claim against company; but no claim existed at time); Gibson $\mathrm{Y}$. National Life \& Accident Ins. Co., 294 S. W. 923 (Tex. Civ. App. 1927) (interpleader). A distinction made by the court in Schoenholz v. New York Life Ins. Co., 197 App. Div. 91, 188 N. Y. Supp. 596 (1st Dep’t 1921) seems unjustified.

73. State ex rel. Richardson v. Mueller, 230 Mro. App. 962, 90 S. W. (2d) 171 (1936) ; Miorgan v. Miutual Benefit Life Ins. Co., 189 N. Y. 447, 82 N. E. 438 (1907); Oishei v. Pennsylvania R. R., 117 App. Div. 110, 102 N. Y. Supp. 368 (1st Dep't 1907), aff'd without opinion, 191 N. Y. 544, 85 N. E. 1113 (1908); Kumor v. Scottish Union \& N. Ins. Co., 47 Wyo. 174, 33 P. (2d) 916 (1934). Accord: Bush v. Missouri State Life Ins. Co., 86 Okla. 182, 207 Pac. 317 (1922) (point not mentioned). But cf. Larson v. Dubuque Fire \& Marine Ins. Co., 238 Mich. 366, 213 N. W. 140 (1927) (under particular facts no situs at place where foreign corporation does business). 
As already indicated, however, some states dissent from the whole conception of a debt as property within the constructive service statutes. ${ }^{74}$ The best statement of this school of thought is contained in the following dictum from First Trust Company of St. Paul v. Matheson.

"A debt or mere right of action with nothing more is wholly incorporeal, with no evidence or representative which can give it habitation anywhere. As to such property . . . sovereign power must proceed in personam simply because there is nothing to take hold on for proceeding in rem or quasi in rem. Hence there can be no jurisdiction to adjudge ownership save as there is jurisdiction in personam over the persons who must be bound in order to settle that issue." 75

This theme, sometimes expressly, sometimes implicitly, pervades the opinions in decisions denying jurisdiction. ${ }^{76}$

It is thus apparent that the courts are sharply divided upon the question of a debt as property within the meaning of the constructive service statutes. Arguments exist for both points of view. But from a practical standpoint, fictionalizing a debt as property will result in a more speedy and less cumbersome method of deciding a dispute if the obligor refuses to pay, for it will necessitate only one lawsuit instead of two. Nor will the nonresident actually suffer any greater hardship than in the case of disputed claims to a negotiable instrument, in which, as we have seen,

74. Austin v. Royal League, 316 Ill. 188, 147 N. E. 106 (1925) (alternative ground of decision; insurance claim not a res) ; MrcBride v. Garland, 89 N. J. Eq. 314, 104 Atl. 435 (1918) (alternative ground of decision; insurance claim not a res); Redzina $v$. Provident Institution for Savings in Jersey City, 96 N. J. Eq. 346, 125 At1. 133 (1924) (bank account); Gallagher v. Rogan, $322 \mathrm{~Pa} .315,185$ Atl. 707 (1936) (statute required presence of chattels or lands, but court based decision on point that bank deposit is not property) ; cf. Williamson v. Falkenhagen, 178 Minn. 379, 227 N. W. 429 (1929) (action to set aside assignment; debtor was not made party nor his residence given; although note involved, court treated like simple debt); J. L. Cocke \& Co. v. Brewer, 68 Miss. 775 , 9 So. 823 (1891) (notes involved, but court treated like simple debt; debtor not party to action, but was subject to court's jurisdiction); National Bank of N. J. v. White, 93 N. J. Eq. 109, 115 Atl. 533 (1921) (interpleader case, but decided partly on point that debt was not res). Each of the three cases last cited, although slightly distinguishable from those directly in point, reached the same result and took the point of view that a debt is not property.

75. 187 Minn. $468,474,246$ N. W. 1,3 (1932).

76. Two Oklahoma cases confuse the law in that state. Bush v. Missouri State Life Ins. Co., 86 Okla. 182, 207 Pac. 317 (1922); Royal Neighbors of America v. Fletcher, 99 Okla. 297, 227 Pac. 426 (1924). In jurisdictions holding that a debt is not a res, payment of the amount into court does not create a res. Vogel v. New York Life Ins. Co., 55 F. (2d) 205 (C. C. A. 5th, 1932), cert. denied, 287 U. S. 604 (1932); cf. Hanna v. Stedman, 230 N. Y. 326, 130 N. E. 566 (1921) ; Bush v. Missouri State Life Ins. Co., 86 Okia. 182, 207 Pac. 317 (1922); Mutual Home Ass'n v. Zwatchka, 297 S. W. 317 (Tex. Civ. App. 1927). Despite misleading language in their respective opinions, neither of the last two cases is contra. See Chafee, Interstate Interpleader (1924) 33 YALE L. J. 685, 710-711. 
the courts allow constructive service. On the other hand, if the obligor is perfectly willing to pay the proper party, two suits will be unnecessary in any event; and the plaintiff, if required to obtain personal jurisdiction over the adverse claimant, will be no more prejudiced than in any other action in personam. ${ }^{\pi 7}$

Putting practical considerations to one side, and treating the general question of debts as property under constructive service statutes from a theoretical angle, it is difficult to regard a debt as a chattel. In the negotiable instrument case there is within the jurisdiction an actual document which is said to embody and merge the underlying debt. But in the case of the simple debt this is not true. It seems doubtful that the constructive service statutes were meant to cover a situation where two people are merely disputing the right to receive payment from a debtor. This is carrying reification a bit too far.

\section{Stock}

The owner of stock in a corporation does not "own" the corporate property or any part thereof. But he does have a right to an aliquot share of the surplus profits, and upon the dissolution of the company he becomes entitled to a share of the surplus assets, i.c., those left after payment of the corporate debts. ${ }^{78}$ That his interest constitutes property in the sense intended by the constructive service statutes is undoulutedly recognized. ${ }^{79}$ It is equally well settled that shares of stock in a corporation

77. For example, if $A$ wishes to set aside an assignment of a claim which he holds against $B$, he may bring an action against the assignee wherever he is able to obtain jurisdiction in personam, and the outcome of the suit will determine the ferson to whom the debt should be paid. However, if there are several claimants, who cannot be serval in the same jurisdiction, the rule that a debt is prorerty within the scope of the constructive service statutes will save $A$ the inconvenience and expense of two or more suits.

78. The matter is well stated in Hook v. Hofiman, 16 Ariz. 540, 546, 147 Pac. 722, 725 (1915); and in Holmes v. Camp, 219 N. Y. 359, 366, 114 N. E. S41, $\$ 43$ (1916). Of course, the stockholder may have other "rights" in the company, such as the right to vote, and, as said in Hook $v$. Hoffman, he has an interest or right in the management of the company.

79. In some of the decisions it appeared that the statutes of the particular state definitely classified corporate stock as personal property. Jellenik v. Huron Copper Mining Co., 177 U. S. 1 (1900) (Michigan statutes); Hodgman v. Atlantic Refining Co., 274 Fed. 104 (D. Del. 1921) ; Thompson v. Terminal Shares, Inc., 89 F. (2d) 652 (C. C. A. Sth, 1937); Bouree ct al. v. Trust Francais Oil Co., 14 Del. Ch. 332, $127 \mathrm{Atl}$. 56 (1924) ; Amparo Mining Co. v. Fidelity Trust Co., 75 N. J. Eq. 555, 73 Atl. 249 (1909). In People's Nat. Bank of Shelbyville v. Cleveland, $117 \mathrm{Ga} .908,44$ S. E. 20 (1903) the Georgia statute provided that stock of corporations holding land was personalty. In the other decisions, cited in subsequent footnotes, the court stated or assumed without question that stock is property for the purpose of allowing construstive service. Language to the contrary in Jones v. Gould, 149 Fed. 153, 157 (C. C. A. 6th, 1906) may be disregarded. See also Comment (1917) 30 HAns. L. REv. 486, disagproving the rule. 
have a situs at the domicil of the corporation. ${ }^{80}$ Whether this situs is exclusive and whether the adoption of the Uniform Stock Transfer Act in many states has modified the rule will be considered subsequently.

Support for the "domicil" rule has been found in statutes" or corporate by-laws or regulations which provide that shares of stock are

80. Cases referring to the Uniform Stock Transfer Act are not included at this point. Unless otherwise noted, the stock certificates were either stated to be outside the jurisdiction or the facts warranted such an assumption. In any event, the court regarded the location of the certificates as immaterial. Jellenik v. Huron Copper Mining Co., 177 U. S. 1 (1900) (principal office and most of corporate property also within district; not clear whether certificates issued, but court treated as though issued and outside state; apparently stock transfer office outside state); Gideon v. Representative Securitics Corp., 232 Fed. 184 (S. D. N. Y. 1916) ; Hudson Navigation Co. v. Murray, 236 Fed. 419 (D. N. J. 1916) (fact complainant wrongfully brought certificates into state immaterial, as presence of certificates unnecessary for jurisdiction; service under New Jersey statutes); Hodgman v. Atlantic Refining Co., 274 Fed. 104 (D. Del. 1921) ; Doherty v. McDowell, 276 Fed. 728 (D. Me. 1921) (corporation had no property in state and did no business in state; annual meeting of stockholders held in state); Thompson v. Terminal Shares, Inc., 89 F. (2d) 652 (C. C. A. 8th, 1937) (service under Missouri statutes); Hook v. Hoffman, 16 Ariz. 540, 147 Pac. 722 (1915); People ex rel. Edinburg State Bank and Trust Co. v. District Court of the Fourteenth District, 97 Colo. 485, 50 P. (2d) 789 (1935); Patterson v. Farmington Street Ry., 76 Conn. 628, 57 Atl. 853 (1904) (certificates not issued) ; Bouree v. Trust Francais, 14 Del. Ch. 332, 127 Atl. 56 (1924) ; Pcrrine v. Pennroad Corp., 19 Del. Ch. 368, 168 Atl. 196 (1933) ; People's Nat. Bank of Shelbyville v. Cleveland, 117 Ga. 908, 44 S. E. 20 (1903); Hamil v. Flowers, 133 Ga. 216, 65 S. E. 961 (1909) (principal office also in state; certificate not issued); Fahrig v. Milwaukee \& Chicago Breweries, 113 Ill. App. 525 (1904) (location of certificate not apparent, but probably outside state); Mrichigan Trust Co. v. Probasco, 29 Ind. App. 109, 63 N. E. 255 (1902) (treated stock as debt) ; Martel v. Block, 154 La. 863, 98 So. 398 (1923) ; Andrews v. Guayaquil \& Q. Ry., 69 N. J. Eq. 211, 60 Atl. 568 (1905), aff'd without opinion for reasons stated in opinion below, $71 \mathrm{~N}$. J. Eq. 768, 71 Atl. 1133 (1906) (place of certificate not apparent).; Sohege v. Singer Mfg. Co., 73 N. J. Eq. 567, 68 At1. 64 (1907); Amparo Mining Co. v. Fidelity Trust Co., 75 N. J. Eq. 555, 73 Atl. 249 (1909); Gagnon v. Roberts, 131 Misc. 126, 226 N. Y. Supp. 385 (Sup. Ct. 1928), aff'd without opinion, 224 App. Div. 723, 229 N. Y. Supp. 858 (1st Dep't 1928) ; Howard v. Marlin-Rockwell Corp., 156 Misc. 358, 281 N. Y. Supp. 666 (Sup. Ct. 1935) (contesting executors); LeRoy Sargent \& Co. v. McHarg, 42 S. D. 307, 174 N. W. 742 (1919) (fact corporation has no property in state immaterial); Gamble v. Dawson, 67 Wash. 72, 120 Pac. 1060 (1912) (contesting administrators). Accord: Baker v. Baker, Eccles \& Co., 242 U. S. 394 (1917) (estate case; determination of domicil of decedent, and consequent ownership of stock, by court other than that at domicil of corporation not entitled to full faith and credit); Clark v. O'Donnell, 68 Colo. 279, 187 Pac. 534 (1920) (defendant appeared, but court also held situs of shares at domicil of corporation); Quarl v. Abbett, 102 Ind. 233, 1 N. E. 476 (1885) (defendant not heard from); Iron City Savings Bank v. Isaacsen, 158 Va. 609, 164 S. E. 520 (1932) (foreign corporation; certificates outside state; decision based on rule that situs is at domicil of corporation); see State ex rel. Methodist Old People's Home v. Crawford, 159 Ore. 377, 389, 80 P. (2d) 873,878 (1938).

81. Hodgman v. Atlantic Refining Co., 274 Fed. 104 (D. Del. 1921); Bouree v. Trust Francais, 14 Del. Ch. 332, 127 Atl. 56 (1924); Perrine v. Pennroad Corp., 19 Del. Ch. 368, 168 Atl. 196 (1933). 
transferable only on the books of the company. ${ }^{82}$ But this is not a very firm base upon which to rest the rule, especially since the true owner of the certificate may compel the corporation to make the transfer on its books. ${ }^{83}$ Furthermore, the requirement that stock shall be transferable only on the books of the company is intended cliefly for the protection of the corporation, to enable it to ascertain its stockholders for purposes of dividends, notices, and the like ${ }^{84}$ and failure to comply with the requirement does not affect the validity of a transfer as between the parties to the transaction. ${ }^{85}$ Another reason given by several courts as a basis for the "domicil" rule is that statutes in the particular state permit attachment or levy of execution on the stock. ${ }^{80}$ Yet so many decisions fail to mention the attachment analogy that it should not be considered the sole or even the principal criterion. . $^{87}$

Still another attempt to rationalize the fiction of situs was represented in the Jellenik case where the court said:

"... the interest represented by the shares is held by the Company for the benefit of the true owner. As the habitation or domicil of the Company is and must be in the State that created it, the property represented by its certificates of stock may lie deemed to be held by the Company within the State whose creature it is. whenever it is sought by suit to deternine who is its real owner." $\$ s$

Even giving due weight to the various theoretical reasons advanced by the courts, they are not entirely convincing. Actually, the stockholder's interest in the corporation has no situs in the sense of location, and the real reasons for pinning a situs onto it are more practical than legalistic. This fact has been recognized in some of the decisions. For instance, in a recent federal case the court said.

"In any event, the corporation's domicil is the most logical place

in which to reach all those who are involved in disputes over the

82. Jellenik v. Huron Copper líining Co., 177 U. S. 1 (1900); Gideon v. Representative Securities Corp., 232 Fed. 184 (S. D. N. Y. 1916); Hook v. Hofiman, 16 Ariz. 540, 147 Pac. 722 (1915); Patterson v. Farmington S. Ry., 76 Conn. 628, 57 Atl. 853 (1904); Amparo Mlining Co. v. Fidelity Trust Co., 75 N. I. Eq. 555, 73 . Atl. 249 (1909); Gamble v. Dawson, 67 Wash. 72, 120 Pac. 10 (1912) (except as between the parties to the transfer).

83. See 12 Fietcher, Corporations (1932) 446 et seq.

S4. Id. at 303 et seq.; see Merritt v. American Steel-Barge Co., 79 Fed. 228, 235

(C. C. A. Sth, 1897).

85. FLETCHER, op. cit. supra note 83 , at 309 ct scq.

86. Jellenik v. Huron Copper Mining Co., 177 U. S. 1 (1900); Doherty v. IrcDowell, 276 Fed. 728 (D. Me. 1921); People's Nat. Bank of Shelbyville v. Cleveland, 117 Ga. 908, 44 S. E. 20 (1903) ; Amparo Mining Co. v. Fidelity Trust Co., 75 X. J. Eq. 555, 73 Atl. 249 (1909); Holmes v. Camp, 219 N. Y. 359, 114 N. E. 841 (1916).

87. For an unusual case, see Amparo Mining Co. v. Fidelity Trust Co., 75 N. J. Eq. 555, 73 Atl. 249 (1909).

8S. 177 U. S. 1,13 (1900). 
title or disposition of stock of the corporation, and it is not straining the legal fiction to say that, for such purposes, the stock constitutes a res in that place." 80

Even more realistically, it has been stated ${ }^{00}$ that stock should be given a situs at the place where the courts can most effectively deal with it. ${ }^{01}$ Several courts, in holding that the situs of stock is the domicil of the corporation, state that the certificates constitute mere evidence of the stockholder's property interest and are not in themselves the property. ${ }^{22}$ In view of this it is rather surprising to find a unanimous array of decisions upholding jurisdiction at the place where the certificate is located. $^{93}$ The opinion in Merritt v. American Steel-Barge Company ${ }^{04}$ reflects the general theory behind these decisions:

"Speaking technically, it is true that a stock certificate is written evidence of a certain interest in corporate property. The same may be said of notes and bills. They are simply evidence of indebtedness on the part of the individuals or corporations who issue them. But in the business world such obligations or securities are treated as something more than mere muniments of title. They are daily bought and sold like ordinary chattels, they may be hypothecated or pledged, they have an inherent market value, and, while differing in some respects from chattels, they are generally classified as personal property." 95

89. McQuillen v. National Cash Register Co., 13 F. Supp. 53, 60 (D. MId. 1935)

90. 75 N. J. Eq. 555, 558, 73 Ati. 249, 250 (1909).

91. The same thought is expressed in Comment (1933) 21 ILL. BAR J. No. 6, at 16-17.

92. Jellenik v. Huron Copper Mining Co., 177 U. S. 1 (1900); Hutson Navigation Co. v. Murray, 236 Fed. 419 (D. N. J. 1916); Hook v. Hoffman, 16 Ariz. 540, 147 Pac. 722 (1915) ; People ex rel. Edinburg State Bank \& Trust Co. v. District Court of Fourteenth District, 97 Colo. 485, 50 P. (2d) 789 (1935) ; Michigan Trust Co. v. Probasco, 29 Ind. App. 109, 63 N. E. 255 (1902) ; Amparo Mining Co. v. Fidelity Trust Co., 75 N. J. Eq. 555, 73 Atl. 249 (1909) ; Gamble v. Dawson, 67 Wash. 72, 120 Pac. 1060 (1912).

93. Merritt v. American Steel-Barge Co., 79 Fed. 228 (C. C. A. 8th, 1897); Ryan v. Seaboard \& R. R. R., 83 Fed. 889 (C. C. E. D. Va. 1897) (place of incorporation not stated) ; Blake v. Foreman Bros. Banking Co., 218 Fed. 264 (N. D. Ill. 1914); Beal v. Carpenter, 235 Fed. 273 (C. C. A. 8th, 1916); Clayton v. Smith, 131 Md. 562, 102 Atl. 925 (1917) (nonresident also demurred for want of equity, but court did not indicate that this constituted appearance; place of incorporation not stated). Accord: Franz v. Buder, 11 F. (2d) 854 (C. C. A. 8th, 1926), cert. denied, 273 U. S. 756 (1927); cf. Vidal v. South American Securities Co., 276 Fed. 855 (C. C. A. 2d, 1921) (certificate plus principal place of business and transfer office); Norrie v. Lohman, 16 F. (2d) 355 (C. C. A. 2d, 1926) (place of certificates plus office for stock transfers, directors' meetings, etc.; follows Vidal case). Baker v. Baker, Eccles \& Co., 242 U. S. 394 (1917) is not contra.

94. 79 Fed. 228 (C. C. A. 8 th, 1897).

95. Id. at 235. It is amusing to note that in Ryan v. Seaboard \& R. R. R., 83 Fed. 889 (C. C. E. D. Va. 1897), the court kept out of trouble by announcing, "A press of engagements prevents an extended discussion of this matter." 
Likewise, the court in Beal $v$. Carpenter ${ }^{90}$ asserted that shares of stock in a corporation are not only evidences of interests in the property of the corporation, "but representatives of those interests having a situs wherever they are present to such an extent that they are property of value which will sustain the jurisdiction of a court to decree the sale and transfer of both the certificates and the interests they represent by its judgment or decree founded on substituted service."

Are the cases holding that the presence of the certificate creates a situs contra to those supporting the "domicil" view? Undoubtedly they are not. It will be recalled that all but one of them were decided by federal courts, and practically all of them concerned the federal constructive service statute. That being true, the Icllenik case, a Supreme Court decision, controls. That case upheld the domicil as a proper situs. It cannot be assumed that later decisions of the lower federal courts were intended to overthrow a Supreme Court decision. Nor is such an assumption necessary. The Jellenik case did not limit jurisdiction to the domicil of the corporation. As remarked in Franz a. Buder:

"It (the Jellenik case) did not hold that it might not also be brought within the jurisdiction where the certificates were held, where the purpose was to test the ownership of such certificates."

The dual situs was also expressly recognized in two of the other federal cases. ${ }^{\text {98 }}$

A possible ground of distinction is suggested by the quotation above from Franz $v$. Buder. Is it possible that the situs is limited to the place of the certificate in cases testing the ownership of the certificate and to the domicil of the corporation in other cases ${ }^{39}$ A laborious investigation of all the cases previously cited - both those upholding the situs at the domicil and those upholding it at the locus of the certificate - brings to light an almost entire absence of discussion on the matter. Outsicle of Hook ' '. Hoffman, ${ }^{100}$ which mentions that the certificate may have a separate situs of its own for certain purposes, such as replevin, and Franz v. Buder, already referred to, the only case seemingly concerned with the question is Gallagher $v$. Rogan. ${ }^{101}$ In refusing jurisdiction at the principal place of business, the holder of the certificate being a non-

96. 235 Fed. 273, 274 (C. C. A. Sth, 1916).

97. 11 F. (2d) 854,859 (C. C. A. Sth, 1926), cert. denied, 273 U. S. 756 (1927).

98. Vidal v. South American Securities Co., 276 Fed. $\$ 55$ (C. C. A. 2d, 1921); Norrie v. Lohman, 16 F. (2d) 355 (C. C. A. 2d, 1926).

99. A variation of this idea appears in Comment (1917) 30 HARv. L. REv. 486.

100. 16 Ariz. 540, 147 Pac. 722 (1915).

101. $322 \mathrm{~Pa} .315,185 \mathrm{Atl} .707$ (1936). The court merged the situs of the certifientes into the domicil of the owner, which is not the law, but that does not destroy the case as authority on the point now under discussion. Nor does the fact that this was an intercounty rather than an interstate case make any difference, because constructive service was made pursuant to a statute requiring that there be property in the county. 
resident of the county, the court distinguished the matter before it from the situation in the Jellenik case. In the Jellenik case the directors of the company caused a fraudulent sale of the plaintiff's stock and bought it in themselves. Plaintiff sued to remove a cloud on the title to his stock. There was no contest over the ownership of any particular certificate. In Gallagher $v$. Rogan, on the other hand, plaintiff brought suit to set aside a transfer of the stock as represented by the certificate, upon the ground that the transfer was procured by fraud and undue influence. With the exception of the Gallagher case, however, the courts have upheld jurisdiction at the domicil of the corporation, even though the action concerned a contest over the shares represented by a particular certificate, to which plaintiff claimed ownership or some right, legal or equitable. ${ }^{102}$ They consider the presence of the certificate unnecessary, because, the corporation being before them, they have the power to order a transfer on the corporate books and a cancellation of the outstanding certificate.

The decisions allowing jurisdiction in rem at the locale of the certificate $^{103}$ relate for the most part to dealings concerning the certificate or the shares represented by a particular certificate. Three of them were actions to foreclose liens on the stock, which had been pledged to the plaintiff. ${ }^{10.4}$ Another was treated by the court as though solely an action to obtain a certain designated certificate, although actually plaintiff asked that all reissues of new certificates for the shares named be declared void. ${ }^{105}$ In Clayton v. Smith ${ }^{106}$ plaintiff sought an order releasing thirty of eighty shares held by a bank as security for a loan. Under the circumstances of the case the suit may properly be said to have concerned an interest in certain shares and the certificate evidencing them. ${ }^{107}$

Thus far, the result of the decisions appears to be that actions in $\mathrm{rcm}$ concerning rights in a particular certificate may be brought at either the domicil of the corporation or the place where the certificate is located. ${ }^{108}$

102. Gideon v. Representative Securities Corp., 232 Fed. 184 (S. D. N. Y. 1916); Doherty v. McDowell, 276 Fed. 728 (D. Me. 1921) ; People's Nat. Bank of Shelbyville v. Cleveland, 117 Ga. 908, 44 S. E. 20 (1903) ; Hamil v. Flowers, 133 Ga. 216, 65 S. E. 961 (1909); Amparo Mining Co. v. Fidelity Trust Co., 75 N. J. Eq. 555, 73 Atl. 249 (1909); Holmes v. Camp, 219 N. Y. 359, 114 N. E. 841 (1916).

103. See note 93 supra.

104. Merritt v. American Steel-Barge Co., 79 Fed. 228 (C. C. A. 8th, 1897); Blake v. Foreman Bros. Banking Co., 218 Fed. 264 (N. D. Ill. 1914); Beal v. Carpenter, 235 Fed. 273 (C. C. A. 8th, 1916).

105. Ryan v. Seaboard \& R. R. R., 83 Fed. 889 (C. C. E. D. Va. 1897).

106. 131 Md. 562, 102 Atl. 925 (1917).

107. Although Franz v. Buder, 11 F. (2d) 854 (C. C. A. 8th, 1926), cert. denicd, 273 U. S. 756 (1927) dealt with an action to quiet title to plaintiff's interest in stock held in trust, the court seemed to deal with the situation as though it involved a contest over the ownership of a certificate. The trust res theory would appear to be a better basis.

108. Even though plaintiff does not claim ownership of or an interest in the particular certificate, presence of the certificate should permit jurisdiction in rem in a suit for surrender and cancellation. 
As to possible siti other than the domicil of the corporation and the place of the certificate, three decisions should be noted. ${ }^{103}$

In Wait v. Kern River Mining, Milling \& Developing Company, ${ }^{110}$ the following combination of factors led the court to authorize constructive service, although the company was a foreign corporation: (1) corporation organized for sole purpose of doing business in California ; (2) all its property in California; (3) all its business transacted in California; (4) its office in California. The court based its decision upon the point that, in substance, the corporation was a domestic one.

Smith v. Pilot Mining Company ${ }^{\mathbf{1 1 1}}$ upheld constructive service under the following combination of facts: (1) no office in state of incorporation; (2) could not be served with summons in state of incorporation; (3) all business done in Missouri; (4) stock books in Missouri; (5) all corporate meetings held in Missouri.

The court reached the opposite result in Iron City Sazings Bunk a'. Isaacsen. ${ }^{112}$ The combination of factors there, however, was wealier, consisting only of principal office, plus records and books. The court actually based its decisions upon the ground that, since the Uniform Stock Transfer Act, a situs no longer exists at the domicil in the absence of seizure of the certificate or a valid injunction against its transfer. ${ }^{113}$ But the court stated that, even without the Act, no jurisdiction would exist under the facts given.

There is no doubt of the correctness of the $W$ ait and Smith cases. Any other ruling would have been absurd. But the situation in the Iron City Sazings Bank case might give rise to heated argument were it to occur again. If the principal office, housing the tranfer books, is within the state or district, and the court has obtained personal service on the corporation, it seems rather foolish to reject jurisdiction upon the technical ground that the domicil is elsewhere. ${ }^{114}$

The effect of the Uniform Stock Transfer Act upon the law of situs of stock in actions to settle conflicting claims will now be considered.

109. In Vidal v. South American Securities Co., 276 Fed. 855 (C. C. A. 2d, 1921), the combination of the certificate plus the principal office, containing the transfer boolss, was present; and in Norrie v. Lohman, 16 F. (2d) 355 (C. C. A. 2d, 1926) the combination of the certificates plus an office for stock transfers, directors' meetings, and the like sufficed. In the $V$ idal case the court stressed the principal office rather than the presence of the certificates. The Norrie case seemed to treat them as about equal in importance, but since it expressly followed the Vidal case, perhaps the court meant to emphasize the presence of the office. The Vidal decision recognized the "domicil" rule, but did not treat it as exclusive.

110. $157 \mathrm{Cal}$. 16, $106 \mathrm{Pac}$ 98 (1909).

111. 47 Mo. App. 409 (1S91).

112. 158 Va. 609,164 S. E. 520 (1932).

113. UnIForar Stock Transfer Act $\$ 13$.

114. As will be shown later, however, the absence of the certificate justifies the decision. 
In the first place, before adoption of the Act, the existence of an outstanding certificate outside the state of domicil did not prevent the courts from taking jurisdiction on constructive service. ${ }^{115}$ In at least three of the cases the court expressly stated that the quasi-negotiable quality of the stock certificate, with the resulting possibility of its transfer to an innocent purchaser for value, was not a deterrent to the assumption of jurisdiction. ${ }^{116}$ Presumably the other courts were aware of the same possibility. Not one of these courts, however, definitely expressed any view as to the priority between the plaintiff, to whom the stock might be awarded by the decree of the court, and a subsequent innocent purchaser of the certificate for value. Yet it seems that this is a matter of paramount importance. If the law of the particular state protects the innocent purchaser for value of the certificate against the plaintiff, the assumption of jurisdiction is an empty gesture. But if the true basis for jurisdiction in rem is a matter of practicality, would it not be advisable for the court at the domicil to refuse jurisdiction if a certificate is outstanding? ${ }^{117}$ However that may be, the specter of an innocent purcliaser for value lurking in the mise en scène in no way frightened the courts away from taking jurisdiction. What is there in the Uniform Stock Transfer Act to make them change their tune? Before the Act, certificates of stock possessed a certain degree of negotiability. For example, "one who had clothed another with the indicia of ownership was estopped to assert his ownership against a bona fide purchaser for value." ${ }^{118}$ Nevertheless, the courts held the domicil of the corporation a proper situs of the stock. What does the Uniform Act contain which warrants one in saying that it changes the law in this respect? True, it increases the number of situations in which a bona fide purchaser for value is entitled to protection, but that effects no essential change so far as the instant problem is concerned. It merely increases the number of lurking specters.

Does Section 13 of the Act affect the problem? It prohibits attachment or levy upon shares of stock for which a certificate is outstanding until the certificate is seized by the officer making the attachment or levy,

115. The cases cited supra note 102 are in point on this problem. Also, Hook $v$. Hoffman, 16 Ariz. 540, 147 Pac. 722 (1915) ; cf. Patterson v. Farmington Strect Ry., 76 Conn. 628, 57 Atl. 853 (1904).

116. Hook v. Hoffman, supra note 115; Amparo Mining Co. v. Fidelity Trust Co, ; and Holmes v. Camp, supra note 102.

117. The question of priority between the person to whom the court decrees the ownership of the stock and the innocent purchaser for value of the certificate need not be settled here, if, indeed, it can be. Cook treats the situation as analogous to that of a creditor levying an attachment on defendant's stock at the domicil of the corporation, and thereafter the defendant, a nonresident, transfers his certificate to an innocent purchaser for value. His claim is that the attaching creditor prevails. 2 CoOK, CoRPorations (8th ed. 1923) 1335,1609 . But evidently this is not true in all states. See Commissioners' Note to Section 13, Uniforar Stock Transfer Act.

118. Pomerance, The "Situs" of Stock (1932) 17 Cons. L. Q. 43, 49. 
or is surrendered to the corporation, or its transfer by the holder is enjoined. So far as attachment and levy of execution are concerned, the section terminates the danger of transfer to an innocent purchaser for value, and eliminates the domicil as a basis for situs in attachment and execution. Of course, it must be admitted that the danger of transfer is not entirely excluded, for in a case where jurisdiction is obtained by injunction, rather than by control over the certificate, defendant may yet transfer to an innocent purchaser for value. Presumably, however, his liability to contempt proceedings will prevent his taking any such rash step.

Is Section 13 broad enough to include cases of conflicting claimants? In words it deals only with attachment and levy. Admittedly, the same difficulty is involved; namely, transfer to an innocent purchaser for value. But is it accurate to hold that, because Section 13 has remedied the defect with relation to attachment, it has done so with relation to conflicting claimant cases not even mentioned in the section? Perhaps one may argue that the last sentence of the section does the trick. That sentence reads:

"Except where a certificate is lost or destroyed, such corporation shall not be compelled to issue a new certificate for the stock until the old certificate is surrendered to it."

Considered apart from the context, this sentence might readily be interpreted as including a conflicting claimant case. If so interpreted, it would probably result in the court's refusal to assume jurisdiction unless it could get hold of the certificate, for under the statutory provision the court would have no right to order the issuance of a new certificate to the plaintiff, and a decree of ownership would produce a rather hollow victory. Possibly, however, the sentence should not be torn from its surroundings and should be interpreted as applying to attachment and execution cases only. 119

Is Section 1 of assistance? That section provides that title to a certificate and to the shares represented thereby can be transferred only by delivery and indorsement of the certificate, or by delivery of the certificate and a separate assignment or power of attorney. It states further that its provisions shall apply, although the charter, articles of incorporation, regulations, or by-laws provide for transferability only on the books of the corporation.

This raises a more difficult situation than Section 13. In reciting that certain methods of transfer shall be the only ones, does it intend to deprive the courts of their hitherto exercised right to order the corporation to make a transfer on its books? Is it not more accurate to hold that the section refers only to voluntary transfers, not to transfers ordered by

119. But see Comment (1935) 45 YALE L. J. 379, expressing the view that Soction 13 should be regarded as divesting the domicil of the corporation of jurisdiction to determine ownership of stock. 
a court? Yet the trouble with this view is that the section is not limited to transfer of title to a certificate, but includes transfer of title "to the shares represented thereby." If the intangible interest of the shareholder cannot be transferred, except by delivery of the certificate (with the additional requirements named in the section), would it not behoove a court at the domicil of the corporation to say, "I have no jurisdiction to order a transfer of the certificate, because the certificate and its holder are outside the jurisdiction. Since $I^{\star}$ have no right to order a transfer of the certificate, I have no right to order the corporation to transfer the shares on its books, for Section 1 of the Uniform Act tells me that title to the shares passes only with title to the certificate?"

The Commissioners' Note to Section 1 declares that the fundamental purpose of the whole Act is to constitute the certificate the representative of the shares. This should lead courts to interpret the Act accordingly. In the particular problem posed, which is not specifically dealt with by Section 1, the Commissioners' Note should influence courts to abrogate the rule that stock has a situs at the domicil, in cases where a certificate is outstanding and neither the certificate nor the holder is subject to the court's jurisdiction; provided, of course, that the action is one in which transfer of the certificate might nullify the decree.

Section 8 is the final one pertinent to this problem:

"Although the transfer of a certificate or of shares represented thereby has been rescinded or set aside, nevertheless, if the transferee has possession of the certificate or of a new certificate representing part or the whole of the same shares of stock, a subsequent transfer of such certificate by the transferee, mediately or immediately, to a purchaser for value in good faith, without notice of any facts making the transfer wrongful, shall give such purchaser an indefeasible right to the certificate and the shares represented thereby."

Now, who would have power to set aside a transfer except a court? Does the section, then, intend to give a court at the domicil of the corporation jurisdiction to set aside the transfer despite the existence out of the state of an outstanding certificate? Presumably not. Apparently the section means to make clear that the innocent purchaser for value takes priority over the plaintiff in the action to set aside the transfer. It neither confers nor takes away jurisdiction. Nevertheless, in line with the argument previously advanced, the section furnishes a court at the domicil with a good reason for refusing to take jurisdiction; for by its terms it renders a decree awarding title to the plaintiff potentially ineffective, to say nothing of the possible prejudice to the corporation resulting from such a decree.

It is to be concluded, then, that by reason of Section 1, taken in connection with the Commissioners' Note thereto; of Section 8 and its effect 
upon a decree awarding ownership; and, possibly, of the last sentence of Section 13, the courts should hold that under the Uniform Stock Transfer Act stock no longer has a situs based upon the domicil of the corporation in any action dealing with conflicting claims of ownership of a particular certificate or the shares represented thereby, or in any other action in which the transfer of an absent certificate to an innocent purchaser for value would nullify the decree. Technically, Section 8, taken alone, does not change the law in a state which previously gave priority to the innocent purchaser for value; but, as pointed out, the law respecting priority was not clearly defined, and Section 8 forcefully reminds a domiciliary court of the futility of taking jurisdiction under the circumstances. ${ }^{120}$

How stand the cases on the question? The language in some of the decisions would lead one to believe that the Uniform Stock Transfer Act has not altered the "domicil-situs" rule in conflicting claim cases. ${ }^{121}$ The cases cited apparently adhered to the rule, as did $M c Q u$ uillen $\because$. National Cash Register Company, ${ }^{122}$ in which the court refused to qualify the Jellenik decision, despite the adoption of the Uniform Act, in the absence of a Supreme Court decision so requiring. But in two of the three cases no question of title was involved. ${ }^{123}$ On the other hand, a Virginia case of comparatively recent vintage holds that in an action to set aside a transfer of stock as fraudulent, the situs under the Uniform Act is where the certificate is situated, and not at the domicil of the corporation. ${ }^{104}$ This decision represents the better view and doubtless will be followed in the future.

120. Of course, even if the certificate were present, the court would have no jurisdiction to order an absent holder to transfer it, but an order for surrender and cancellation would seem both proper and effective. Armed with such an order and in possession of the surrendered certificate, plaintiff should be able to compel the corporation to issur a new certificate to him.

121. See Harvey v. Harvey, 290 Fed. 653, 659 (C. C. A. 7th, 1923); Shinlile v. Dalton Adding Machine Co. of Ohio, 19 Ohio N. P. (s.s.) 104, 108, 26 Ohio Dee. (z..P.) 588, 591 (C. P. 1916).

122. 13 F. Supp. 53 (D. MId. 1935).

123. The Hariey and Shinkle cases, supra note 121, concerned voting rights. The McQuillen case, supra note 122, concerned an action to cancel certain stock alleged to have been illegally issued to the defendants. The plaintiffs claimed that the allegedly illegal issue constituted a cloud on the title to their own stock. Although the opinion is not entirely clear, the case is probably contra to the interpretation advanced here of the effect of the Uniform Stock Transfer Act.

124. Iron City Savings Bank v. Isaacsen, 158 Va. 609, 164 S. E. 520 (1932). A federal case, Klein v. Wilson \& Co., Inc, 7 F. (2d) 769 (D. N. J. 1924), took the same view in an action for the appointment of a receiver, holding that ownership of stocls in a domestic corporation did not constitute "property" in the state, the certificates being outside. Although the case did not involve a dispute concerning title, there was a certificate in existence and away from the jurisdiction of the court, and it might have been transferred to a bona fide purchaser for value. 


\section{Conclusion}

In the foregoing study an attempt has been made to discover whether various forms of intangibles are treated as property for the purpose of validating constructive service in actions in rem against nonresident claimants; and to determine the situs of those forms of intangibles so treated. From the authorities examined, certain general conclusions are warranted. ${ }^{125}$

1. The following types of intangibles are regarded as property in the required sense :

a. Bonds;

b. Bills, notes and checks (at least if negotiable);

c. "Funds" in the possession of administrators, executors, trustees or receivers;

d. Shares of stock.

2. Insurance policies are not property in the required sense.

3. The authorities are not in agreement as to whether debts come within the term "property" as used in constructive service statutes. The view that they do not seems more in accord with the purpose and policy of such statutes.

4. Of the intangibles regarded as property, the situs of bonds and of negotiable bills, notes, and checks ${ }^{126}$ is governed by the law relating to the situs of chattels. In other words, these instruments are considered property separate and apart from the obligations which they represent.

5. Prior to the adoption of the Uniform Stock Transfer Act shares of stock apparently had a situs at either the domicil of the corporation or the locale of the stock certificate. In most states controlled by the Uniform Act the law is not yet settled. The courts of such states should hold that in actions relating to conflicting claims of ownership in a particular certificate or the shares represented thereby, the sole situs is at the location of the certificate. In other actions the pre-existent rules will apply.

6. In jurisdictions embracing debts within the term "property," the situs of a debt is not limited to the domicil of the debtor, but includes any place where jurisdiction in personam may be obtained over him.

7. The cases dealing with "funds" have not presented any difficulty with reference to situs. In most of them the fiduciary and the estate were under the supervision of a local court, and in the others both the fiduciary

125. This summary is not intended to be exhaustive. Its purpose is to present in abbreviated form the more important conclusions arrived at. Exceptions and modifications are not repeated here.

126. Although none of the cases cited concerned checks, it seems logical to classify them with bills and notes. 
and the depositary were within the jurisdiction. The interesting situation of a fiduciary whose funds are deposited outside the state has apparently not come to the attention of the courts. Doubtless in the case of estates in process of administration in a particular county or district, funds under the supervision of the appropriate court will be held to have a situs therein regardless of the place of their deposit or the domicil of the fiduciary. But where trust funds are not in the control of a court, a nice question of situs may arise as between the domicil of the fiduciary and the place where the account is deposited. 